Volume 1, No. 1, April 2021

\title{
HUKUM ADMINISTRASI NEGARA \\ DALAM UPAYA PENYELENGGARAAN PEMERINTAHAN YANG BAIK
}

\author{
Syahrul Ibad \\ Program Studi Hukum Fakultas Ilmu Sosial dan Humaniora \\ Universitas Ibrahimy Situbondo \\ Email: sinbad.sit@gmail.com.
}

\begin{abstract}
Abstrak
Pelaksanaan pelayanan publik sering kali pemerintah di dalam menggunakan kewenangannya yang telah di atur oleh undang-undang tidak sesuai dengan dengan apa yang di harapkan. beberapa fungsi hukum administrasi negara dalam menciptakan penyelenggaraan pemerintahan yang baik memang sangat dibutuhkan antara lain fungsi normatif, fungsi instrumental, dan fungsi jaminan hukum yang ketiganya merupakan sebagian dari penerapan agar tercipta pemerintahan yang bersih, sesuai dengan prinsip-prinsip negara hukum. Tulisan ini memfokuskan pada fungsi hukum administrasi negara dalam menciptakan penyelenggaraan pemerintahan yang baik dan upaya hukum administrasi negara dalam meningkatkan penyelenggaraan pemerintahan yang baik. Metode penelitian yang digunakan adalah penelitian kualitatif, Dengan metode penulisan yang dimaksud meliputi empat aspek, yaitu tipe penulisan, pendekatan masalah, sumber bahan hukum dan analisa bahan hukum. Hasil yang dapat disajikan dalam tulisan ini adalah fungsi hukum administrasi negara ada yaitu fungsi normatif, fungsi instrumental, dan fungsi sebagai jaminan hukum. Sedangkan upaya hukum administrasi negara yang di tuangkan dalam bentuk pengawasan, baik pengawasan secara internal dan pengawasan eksternal yang keduanya bersinergi untuk mewujudkan penyelenggara pemerintahan yang baik.
\end{abstract}

Kata Kunci: Hukum Administrasi Negara, Penyelenggaraan Perintahan, Pemerintah yang Baik.

\begin{abstract}
The implementation of public services is often the government in using its authority which has been regulated by law not in accordance with what is expected. Several functions of state administrative law in creating good governance are really needed, including normative functions, instrumental functions, and legal guarantee functions, all three of which are part of the implementation in order to create a clean government, in accordance with the principles of the rule of law. This paper focuses on the function of state
\end{abstract}


administrative law in creating good governance and state administrative law efforts in improving good governance. The research method used is qualitative research, with the writing method in question covering four aspects, namely the type of writing, problem approach, sources of legal materials and analysis of legal materials. The results that can be presented in this paper are the functions of state administrative law, namely normative functions, instrumental functions, and functions as legal guarantees. While the legal efforts of state administration are poured in the form of supervision, both internal supervision and external supervision, both of which synergize to realize good governance.

Keywords: State Administrative Law, Order Execution, and Good Government.

\section{PENDAHULUAN}

\section{A. Latar Belakang}

Hukum administrasi negara (HAN) sebagai suatu cabang ilmu, khususnya di wilayah hukum kontinental, baru muncul belakangan. Pada awalnya, khususnya di negeri Belanda, hukum administrasi negara menjadi suatu kesatuan dengan hukum tata negara dengan nama staat en administratief recht. Agak berbeda dengan yang berkembang di Perancis sebagai bidang tersendiri di samping hukum tata negara, dan selain itu "het bestuursrecht vormt in vergelijking tot het privaatrecht en het strafrecht een relatifjong rechtsgebied"1

Di Belanda ada dua istilah mengenai hukum ini yaitu bestuursrecht dan administratief recht. Terhadap dua istilah ini para sarjana Indonesia berbeda pendapat dalam menterjemahkannya. Untuk kata administratief ini ada yang menterjemahkan dengan tata usaha, tata usaha pemerintahan, tata pemerintahan, tata usaha negara, dan ada yang menterjemahkan secara seragam dengan administrasi saja, sedangkan kata bestuur diterjemahkan secara seragam dengan pemerintahan.

Perbedaan penterjemahan tersebut mengakibatkan penamaan terhadap hukum ini, yakni seperti HAN, Hukum Tata Pemerintahan, Hukum Tata Usaha Pemerintahan, Hukum Tata Usaha Negara Indonesia, dan Hukum Administrasi,

1 Kuntjoro Purboprnoto, Beberapa Catatan Hukum Tata Pemerintahan dan Peradilan Administrasi Negara, (Bandung: Alumni, 1975). hlm. 12-19.

56 HUKMY|Jurnal Hukum 
tanpa atribut negara, sebagaimana yang dianut Hadjon, dengan alasan bahwa pada kata administrasi itu sudah mengandung makna konotasi negara/ pemerintahaan. Adanya keragaman istilah ini dalam perkembangannya lebih mengarah pada penggunaan istilah HAN dibandingkan istilah lainnya. Disamping itu pula peran HAN dalam pemerintahan yang ada saat ini sangatlah mempengaruhi terhadap kegiatan yang dilakukan oleh seluruh aparatur pemerintah dari suatu negara dalam usaha mencapai tujuan suatu negara. ${ }^{2}$

Di lain sisi fungsi hukum administrasi negara dalam menciptakan penyelenggaraan pemerintahan yang baik dan berwibawa memang sangat dibutuhkan. Salah satu agenda pembangunan nasional adalah menciptakan tata pemerintahan yang bersih, dan berwibawa. Agenda tersebut merupakan upaya untuk mewujudkan tata pemerintahan yang baik, antara lain: keterbukaan, akuntabilitas, efektifitas dan efisiensi, menjunjung tinggi supremasi hukum, dan membuka partisipasi masyarakat yang dapat menjamin kelancaran, keserasian dan keterpaduan tugas dan fungsi penyelenggaraan pemerintahan dan pembangunan. Untuk itu diperlukan langkah-langkah kebijakan yang terarah pada perubahan kelembagaan dan sistem ketatalaksanaan, kualitas sumber daya manusia, aparatur, dan sistem pengawasan dan pemeriksaan yang efektif.

Pemerintah juga sebagai alat kelengkapan negara dapat diartikan secaraluas (in the board sense) dan dalam arti sempit (in the narrow sense). Pemerintah dalam arti luas mencakup semua alat kelengkapan negara, yang pada pokoknya terdiri dari cabang-cabang kekuasaan eksekutif, legislatif, dan yudikatif, atau alat- alat kelengkapan negara lain yang bertindak dan untuk atas nama negara, sedangkan dalam pengertian sempit pemerintah adalah cabang kekuasaan eksekutif. ${ }^{3}$ Pemerintahan dalam arti sempit adalah organ atau alat perlengkapan negara yang diserahi tugas pemerintahan atau melaksanakan undang-undang,

2 Sondang P. Siagian, Filsafat Administrasi, (Jakarta, Gunung Agung, 1986), hlm.8.

3 Bagir Manan dan Kuntana Magnar, Beberapa Masalah Hukum Tata Negara Indonesia, (Bandung: Alumni, 1997). hlm. 158-159. 
sedangkan dalam arti luas mencakup semua badan yang menyelenggarakan semua kekuasaan di dalam negara baik eksekutif maupun legislatif dan yudikatif. ${ }^{4}$

\section{B. Perumusan Masalah}

Beberapa pokok pikiran di atas, perlu dikaji dan mengkaji permasalahan mengenai peranan dan fungsi Hukum Administrasi Negara dalam suatu karya ilmiah yang menekankan pada fungsi hukum administrasi negara dalam penyelenggaraan pemerintahan yang baik dan upaya hukum administrasi negara dalam meningkatkan penyelenggaraan pemerintahan yang baik.

\section{Metode Penelitian}

Metode penelitian yang digunakan adalah penelitian kualitatif, menurut menurut Miles, Huberman dan Saldana mendefinisikan penelitian deskriptif adalah metode yang digunakan untuk menggambarkan atau menganalisis suatu hasil penelitian tetapi tidak digunakan untuk membuat kesimpulan yang luas. ${ }^{5}$ Metode penulisan yang dimaksud meliputi 4 (empat) aspek, yaitu tipe penulisan, pendekatan masalah, sumber bahan hukum dan analisa bahan hukum.

\section{PEMBAHASAN}

\section{Hukum Administrasi Negara Dalam Upaya Penyelenggaraan Pemerintahan yang Baik}

\section{Eksistensi Pemerintah dalam Konsepsi Welfare State Indonesia.}

Berdasarkan ketentuan Pasal 1 ayat (3) UUD Republik Indonesia Tahun 1945 "Negara Indonesia adalah negara hukum yang menganut desentralisasi dalam penyelenggaraan pemerintahan, sebagaimana diisyaratkan dalam Pasal 18 ayat (1) UUD Negara Republik Indonesia Tahun 1945 "negara kesatuan republik Indonesia di bagi atas daerah-daerah provinsi dan daerah provinsi itu dibagi atas kabupaten dan kota, yang tiap-tiap provinsi, kabupaten, dan kota mempunyai pemerintahan daerah yang diatur dengan undang- undang". Diberbagai negara hukum, setiap penyelenggara urusan pemerintahan haruslah berdasarkan pada

4 F. Marbun dan Moh. Mahfud, Pokok-Pokok Hukum Administrasi Negara, (Yogyakarta: Liberty, 1987). hlm. 8.

5 Miles, M.B, Huberman dan Saldana, Qualitative Data Analysis, A Methods Sourcebook. ed. 3, (USA, Sage Publication, 2014).

58 HUKMY|Jurnal Hukum 
hukum yang berlaku (wetmatigheid van bestuur). Sebagai negara yang menganut desentralisasi mengandung arti bahwa urusan pemerintahan itu terdiri atas urusan pemerintahan pusat dan urusan pemerintahan daerah. Artinya ada perangkat pemerintahan pusat dan ada perangkat pemerintahan daerah, yang diberi otonomi yaitu kebebasan dan kemandirian untuk mengatur dan mengurus urusan rumah tangga daerahnya sendiri.

Unsur-unsur yang berlaku umum bagi setiap negara hukum, yakni sebagai berikut:

a. Adanya suatu sistem pemerintahan negara yang didasarkan atas kedaulatan rakyat.

b. Bahwa pemerintah dalam melaksanakan tugas dan kewajibannya harus berdasar atas hukum atau peraturan perundang-undangan.

c. Adanya jaminan terhadap hak-hak asasi manusia.

d. Adanya pembagian kekuasaan dalam negara.

e. Adanya pengawasan dari badan-badan peradilan (rechterlijke controle) yang bebas dan mandiri, dalam arti lembaga peradilan tersebut benar- benar tidak memihak dan tidak berada di bawah pengaruh eksekutif.

f. Adanya peran yang nyata dari anggota-anggota masyarakat atau warga negara untuk turut serta mengawasi perbuatan dan pelaksanaan kebijaksanaan yang dilakukan oleh pemerintah.

g. Adanya sistem perekonomian yang dapat menjamin pembagian yang merata sumberdaya yang diperlukan bagi kemakmuran warga negara.

Unsur-unsur negara hukum ini biasanya terdapat dalam konstitusi. Olehkarena itu, keberadaan konstitusi dalam suatu negara hukum merupakan keharusan. Menurut Sri Soemantri, tidak ada satu negara pun di dunia ini yang idak mempunyai konstitusi atau undang-undang dasar. ${ }^{6}$ Negara dan konstitusi merupakan dua lembaga yang tidak dapat dipisahkan satu dengan yang lain. Apabila kita meneliti UUD 1945, kita akan menemukan unsur-unsurnegara hukum tersebut di dalamnya, yaitu sebagai berikut; pertama, prinsip kedaulatan rakyat (pasal 1 ayat 2), kedua, pemerintahan berdasarkan konstitusi (penjelasan UUD

6 Sri Soemantri, Bunga Rampai Hukum Tata Negara Indonesia, (Bandung, Alumni, 1992). hlm. 25. 
1945), ketiga, jaminan terhadap hak-hak asasi manusia (pasal 27, 28, 29, 31), keempat, pembagian kekuasaan (pasal 2, 4, 16, 19), kelima, engawasan peradilan (pasal 24), keenam, partisipasi warga negara (pasal 28), ketujuh, sistem perekonomian (pasal 33).

Esensi dari negara hukum yang berkonstitusi adalah perlindungan terhadap hak asasi manusia. Oleh karena itu, isi dari setiap konstitusi tersebut dapat dijelaskan sebagai berikut, negara merupakan organisasi kekuasaan berdasarkan kedaulatan rakyat, agar kekuasaan ini tidak liar maka perlu dikendalikan dengan cara disusun, dibagi dan dibatasi, serta diawasi baik oleh lembaga pengawasan yang mandiri dan merdeka maupun oleh warga masyarakat, sehingga tidak terjadi pelanggaran terhadap hak-hak asasi manusia. Seandainya adanya jaminan terhadap hak-hak asasi manusia ini ditiadakan dari konstitusi, maka penyusunan, pembagian, pembatasan, dan pengawasan kekuasaan negara tidak diperlukan karena tidak ada lagi yang perlu dijamin dan dilindungi. Karena esensi dari setiap konstitusi adalah perlindungan terhadap hak-hak asasi manusia, maka menuntut adanya kesamaan derajat setiap manusia di depan hukum. Tiadanya kesamaan akan menyebabkan satu pihak merasa lebih tinggi dari pihak lainnya, sehingga akan mengarah pada terjadinya penguasaan pihak yang lebih tinggi kepada yang rendah. Dengan situasi yang demikian merupakan bentuk awal dari tumbuhnya kesewenang-wenangan yang menyebabkan terlanggarnya hak-hak manusia, dengan adanya hal ini berarti perlindungan terhadap hak-hak asasi manusia yang terdapat dalam setiap konstitusi menjadi tidak berarti atau kehilangan makna.

Adanya kesamaan antar manusia dalam suatu negara akan memungkinkan lahirnya partisipasi yang aktif dari setiap orang. Sehingga partisipasi oleh masyarakat sebuah negara ini penting dalam suatu negara yang memiliki konstitusi, agar isi dari konstitusi sebagai hukum dasar ini merupakan inti dari keinginan-keinginan dan kehendak dari sebagian besar masyarakat sebuah negara. Partisipasi masyarakat dalam suatu negara ini juga merupakan bentuk dari negara yang menjunjung tinggi budaya demokrasi. Eksistensi Indonesia sebagai negara hukum secara tegas disebutkan dalam Penjelasan UUD 1945; "Indonesia ialah negara yang berdasar atas hukum (rechtsstaat)". Indikasi bahwa Indonesia menganut konsepsi welfare state terdapat pada kewajiban pemerintah untuk 60 HUKMY|Jurnal Hukum 
mewujudkan tujuan-tujuan negara, sebagaimana yang termuat dalam alinea keempat Pembukaan UUD 1945, yaitu: “Melindungi segenap bangsa Indonesia dan seluruh tumpah darah Indonesia, memajukan kesejahteraan umum, mencerdaskan kehidupan bangsa, dan melaksanakan ketertiban dunia". Tujuan-tujuan ini diupayakan perwujudannya melalui pembangunan yang dilakukan secara bertahap dan berkesinambungan dalam program jangka pendek, menengah, dan panjang.

\section{Tindakan Pemerintahan dalam Negara Hukum}

Dalam melakukan aktifitasnya, pemerintah melakukan dua macam tindakan, tindakan nyata (feitelijkehandelingen) dan tindakan hukum (rechtshandeli-ngen). Tindakan nyata adalah tindakan-tindakan yang tidak ada relevansinya dengan hukum dan oleh karenanya tidak menimbulkan akibat-akibat hukum. ${ }^{7}$ sedangkan tindakan hukum pemerintahan adalah tindakan yang dilakukan oleh Badan atau Pejabat Tata Usaha Negara dalam rangka melaksanakan urusan pemerintahan. ${ }^{8}$ Tindakan pemerintahan memiliki beberapa unsur yaitu sebagai berikut: ${ }^{9}$

a. Perbuatan itu dilakukan oleh aparat Pemerintah dalam kedudukannya sebagai Penguasa maupun sebagai alat perlengkapan pemerintahan (bestuursorganen) dengan prakarsa dan tanggung jawab sendiri.

b. Perbuatan tersebut dilaksanakan dalam rangka menjalankan fungsi pemerintahan.

c. Perbuatan tersebut dimaksudkan sebagai sarana untuk menimbulkan akibat hukum di bidang hukum administrasi.

d. Perbuatan yang bersangkutan dilakukan dalam rangka pemeliharaan kepentingan negara dan rakyat.

Dalam negara hukum, setiap tindakan pemerintahan harus berdasarkan atas hukum, karena dalam negara terdapat prinsip wetmatigheid van bestuur atau

7 C.J.N Versteden, Inleiding Algemeen Bestuurstrecht, Samsom H.D. Tjeenk Willink, (Alphen aan den Rijn, 1984), hlm. 55.

8 Ibid, hlm. 56.

9 Muchsan, Beberapa Catatan tentang Hukum Administrasi Negara dan Peradilan Administrasi Negara di Indonesia, (Yogyakarta: Liberty, 1981). hlm. 18-19. 
asas legalitas. Asas ini menentukan bahwa tanpa adanya dasar wewenang yang diberikan oleh suatu peraturan perundang-undangan yang berlaku, maka segala macam aparat pemerintah tidak akan memiliki wewenang yang dapat mempengaruhi atau mengubah keadaan atau posisi hukum warga masyarakatnya. Asas legalitas menurut Sjachran Basah, berarti upaya mewujudkan duet integral secara harmonis antara paham kedaulatan hukum dan paham kedaulatan rakyat yang sifat hakikatnya konstitutif. 10

Meskipun demikian, tidak selalu setiap tindakan pemerintahan tersedia peraturan perundang-undangan yang mengaturnya. Dapat terjadi, dalam kondisi tertentu terutama ketika pemerintah harus bertindak cepat untuk menyelesaikan persoalan konkret dalam masyarakat, peraturan perundang-undangannya belum tersedia. Dalam kondisi seperti ini, kepada pemerintah diberikan kebebasan bertindak (discresionare power) yaitu melalui freies Ermessen, yang diartikan sebagai salah satu sarana yang memberikan ruang bergerak bagi pejabat atau badan-badan administrasi negara untuk melakukan tindakan tanpa harus terikat sepenuhnya pada undang-undang.

Freies Ermessen ini menimbulkan implikasi dalam bidang legislasi bagi pemerintah, yaitu lahirnya hak inisiatif untuk membuat peraturan perundangundangan yang sederajat dengan undang-undang tanpa persetujuan DPR, hak delegasi untuk membuat peraturan yang derajatnya di bawah undang-undang, dan droit function atau kewenangan menafsirkan sendiri aturan-aturan yang masih bersifat enunsiatif. Menurut Bagir Manan, kewenangan pemerintah untuk membentuk peraturan perundang-undangan karena beberapa alasan yaitu; Pertama, paham pembagian kekuasaan menekankan pada perbedaan fungsi daripada pemisahan organ, karena itu fungsi pembentukan peraturan tidak harus terpisah dari fungsi penyelenggaraan pemerintahan; Kedua, dalam negara kesejahteraan pemerintah membutuhkan instrumen hukum untuk menyelenggarakan kesejahteraan umum; Ketiga, untuk menunjang perubahan

10 Sjachran Basah, Eksistensi dan Tolok Ukur Badan Peradilan Administrasi Negara, (Bandung: Alumni, 1985). hlm. 20 
masyarakat yang cepat, mendorong administrasi negara berperan lebih besar dalam pembentukan peraturan perundang-undangan. ${ }^{11}$

Freies Ermessen merupakan konsekuensi logis dari konsepsi welfare state, akan tetapi dalam kerangka negara hukum, freies Ermessen ini tidak dapat digunakan tanpa batas. Atas dasar itu, Sjachran Basah mengemukakan unsurunsur freies Ermessen dalam suatu negara hukum yaitu sebagai berikut: a) ditujukan untuk menjalankan tugas-tugas servis public, b) merupakan sikap tindak yang aktif dari administrasi negara, c) sikap tindak itu dimungkinkan oleh hukum, d) sikap tindak itu diambil atas inisiatif sendiri, e) sikap tindak itu dimaksudkan untuk menyelesaikan persoalan-persoalan penting yang timbul secara tiba-tiba,f) sikap tindak itu dapat dipertanggungjawabkan baik secara moral kepada Tuhan Yang Maha Esa maupun secara hukum. ${ }^{12}$

Seiring dengan pilar utama negara hukum, yaitu asas legalitas (legaliteitsbeginsel atau het beginsel van wetmatigheid van bestuur), maka berdasarkan prinsip ini tersirat bahwa wewenang pemerintahan berasal dari peraturan perundang-undangan, artinya sumber wewenang bagi pemerintah adalah peraturan perundang-undangan. Secara teoritik, kewenangan yang dimiliki oleh pemerintah bersumber pada tiga hal, atribusi, delegasi, dan mandat. ${ }^{13}$ Atribusi ialah pemberian kewenangan oleh pembuat undang-undang sendiri kepada suatu organ pemerintahan baik yang sudah ada maupun yang baru sama sekali. Suatu atribusi menunjuk kepada kewenangan yang asli atas dasar ketentuan hukum tata negara. Suatu atribusi merupakan wewenang untuk membuat keputusan (besluit) yang langsung bersumber kepada undang-undang dalam arti materiil. Pendapat lain mengatakan bahwa atribusi merupakan pembentuk wewenang adalah organ yang berwenang berdasarkan peraturan perundang-undangan.

11 Bagir Manan, Peranan Peraturan Perundang-undangan dalam Pembinaan Hukum Nasional, (Bandung: Armico, 1987). hlm. 67.

12 Sjachran Basah, Eksistensi dan Tolok Ukur Badan Peradilan Administrasi Negara, (Bandung: Alumni, 1985). hlm. 43

13 Indroharto, Perbuatan Pemerintah Menurut Hukum Publik dan Hukum Perdata, Bahan Kuliah Pada Program Pendidikan Lanjutan Ilmu Hukum Bidang PTUN, (Jakarta: Universitas Indonesia, 1992). hlm. 91. 
Secara spesifik, fungsi Hukum Administrasi Negara dikemukakan oleh Philipus M. Hadjon, yakni fungsi normatif, fungsi instrumental, dan fungsi jaminan. ${ }^{14}$ Ketiga fungsi ini saling berkaitan satu sama lain. Fungsi normatif yang menyangkut penormaan kekuasaan memerintah jelas berkaitan erat dengan fungsi instrumental yang menetapkan instrumen yang digunakan oleh pemerintah untuk menggunakan kekuasaan memerintah dan pada akhirnya norma pemerintahan dan instrumen pemerintahan yang digunakan harus menjamin perlindungan hukum bagi rakyat.

Berdasarkan pemaparan fungsi-fungsi Hukum Administrasi Negara ini, dapatlah disebutkan bahwa dengan menerapkan fungsi-fungsi Hukum Administrasi Negara ini akan tercipta pemerintahan yang bersih, sesuai dengan prinsip-prinsip negara hukum. Pemerintah menjalankan aktifitas sesuai dengan ketentuan yang berlaku atau berdasarkan asas legalitas, dan ketika menggunakan freies Ermessen, pemerintah memperhatikan asas-asas umum yang berlaku sehingga dapat dipertanggungjawabkan secara moral dan hukum. Ketika pemerintah menciptakan dan menggunakan instrumen yuridis, maka dengan mengikuti ketentuan formal dan material penggunaan instrumen tersebut tidak akan menyebabkan kerugian terhadap masyarakat. Dengan demikian, jaminan perlindungan terhadap warga negarapun akan terjamin dengan baik.

\section{Upaya Hukum Administrasi Negara dalam Meningkatkan Penyelenggaraan Pemerintahan yang Baik}

Dalam hukum administrasi negara pemerintah memiliki dua kedudukan yaitu: pertama, kedudukan Pemerintah dalam hukum public yaitu dalam konteks pandangan hukum publik, maka negara dapat dianggap sebagai organisasi jabatan.57 Organisasi jabatan merupakan sistem kerjasama dari kegiatan pemerintah dalam menjalankan pemerintahan, namun di dalam menjalankan segala bentuk kegiatannya pemerintah harus berdasarkan dan sesuai dengan peraturan serta undang-undang yang ada. Diantara jabatan-jabatan kenegaraan

\footnotetext{
${ }_{14}$ Philipus M. Hadjon, Pengantar Hukum Administrasi Indonesia. (Yogyakarta: Gajahmada University Press, 1993). hlm. 124
}

64 HUKMY|Jurnal Hukum 
yang seringkali ditemui, maka ada yang namanya jabatan pemerintahan. Dalam pandangan H.D van Wijk dan Willem Konijnenbelt, di dalam hukum mengenai badan hukum dan organ-organnya. Badan hukum adalah pendukung hak-hak kebendaan (harta kekayaan). Lebih lanjut meraka mengatakan badan hukum melakukan perbuatan melalui organ-organ yang mewakilinya.

Perbedaan antara badan hukum dengan organ berjalan paralel dengan perbedaan antara badan umum dengan organ pemerintahan. Paralelitas perbedaan itu kurang lebih tampak ketika menyangkut hubungan hukum yang berkaitan dengan harta kekayaan dari badan umum yang digunakan oleh organ pemerintahan. ${ }^{15}$ Kaitannya dengan hal tersebut, lembaga-lembaga hukum publik itu memiliki kedudukan yang mandiri dalam statusnya yang menjadi induk dari badan atau jabatan tata usaha negara yang besar-besar diantaranya adalah negara, lembaga- lembaga tertinggi, dan tinggi negara, departemen, badan-badan non departemen, provinsi, kabupaten, kotamadya, dan sebagainya. Lembaga-lembaga hukum publik tersebutmerupakan badan hukum perdata dan melalui organorgannya (Badan atau Jabatan Tata Usaha Negara) menurut peraturan perundangundangan yang bersangkutan dapat melakukan perbuatan/tindakan hukum perdata.

Yang kedua, kedudukan pemerintah dalam hukum privat yaitu dikatakan bahwa subyek hukum adalah segala sesuatu yang dapat memperoleh hak dan kewajiban dari hukum. Yang dapat memperoleh hak dan kewajiban hanyalah manusia atau orang atau sesuatu yang dapat di persamakan dengan orang yang sering kita kenal dengan istilah badan hukum. Badan hukum itu bertindak sebagai suatu kesatuan dalam lalu lintas hukum seperti orang. Hukum menciptakan badan hukum oleh karena manusia sebagai subyek hukum itu sangat diperlukan karena hal itu bermanfaat bagi lalu lintas hukum dan secara bebas sesuai pendapat beberapa ahli hukum, dapat dikatakan bahwa badan hukum ini merupakan ruang lingkup keperdataan.

15 Ridwan HR., Hukum Administrasi Negara, cetakan ketujuh. (Jakarta: PT Raja Grafindo Persada, 2011). hlm. $72-73$ 
Berdasarkan keterangan tersebut tampak bahwa tindakan hukum pemerintahan di bidang keperdataan adalah sebagai wakil dari badan hukum (rechtpersoon), yang tunduk dan diatur dengan hukum perdata. Dengan demikian, kedudukan pemerintahan dalam hukum privat adalah sebagai wakil dari badan hukum keperdataan. Ketika pemerintah akan menjalankan pemerintahan, maka kepada pemerintah diberikan kewenangan dan kekuasaan, yang dengan kekuasaan dan kewenangan ini pemerintah melaksanakan pembangunan, peraturan dan pelayanan.

Dengan adanya kedudukan pemerintah yang demikian, penyelenggaraan pemerintahan tidak selalu berjalan sebagaimana yang telah ditentukan oleh aturan yang ada. Bahkan sering terjadi penyelenggaraan pemerintahan ini menimbulkan kerugian bagi rakyat baik akibat penyalahgunaan wewenang (detournement de pouvoir) maupun tindakan sewenang-wenang (willekeur). Perbuatan pemerintah yang sewenang-wenang terjadi apabila terpenuhi unsur-unsur; pertama, penguasa yang berbuat secara yuridis memiliki kewenangan untuk berbuat (ada peraturan dasarnya); kedua, dalam mempertimbangkan yang terkait dalam keputusan yang dibuat oleh pemerintah, unsur kepentingan umum kurang diperhatikan; ketiga, erbuatan tersebut menimbulkan kerugian konkret bagi pihak tertentu. ${ }^{16}$ Dampak lain dari penyelenggaraan pemerintahan seperti ini adalah tidak terselenggaranya pembangunan dengan baik dan tidak terlaksananya pengaturan dan pelayanan terhadap masyarakat sebagaimana mestinya. Keadaan ini menunjukan penyelenggaraan pemerintahan belum berjalan dengan baik. Sehingga harus ada upaya yang di tempuh dalam mewujudkan pemerintahan yang jauh lebih baik yaitu dengan cara: pengawasan internal penyelenggara pelayanan publik dan pengawasan eksternal penyelenggara pelayanan publik.

\section{Pengawasan Internal Penyelenggara Pelayanan Publik}

Pengawasan secara internal dalam penyelenggara pelayanan publik dilaksanakan oleh: atasan langsung pada setiap unit satuan kerja atau satuan organisasi atau satuan kerja perangkat daerah (SKPD) pada setiap institusi,

\footnotetext{
16 Iskratinah, "Pelaksanaan Fungsi Hukum Administrasi Negara”, makalah 2007
} 
korporasi, lembaga independen untuk kegiatan pelayanan publik, dan badan hukum lain yang dibentuk semata-mata untuk kegiatan pelayanan publik; dan pengawasan fungsional sesuai peraturan perundang-undangan. Pengawasan melekat (atasan langsung) pada hakikatnya adalah untuk mencegah secara dini terjadinya masalah penyalahgunaan wewenang, pemungutan biaya yang tidak prosedural, proses pelayanan yang berbelit-belit, tidak disiplinnya petugas pemberi pelayanan publik terhadap pihak yang menerima pelayanan, dan praktik mal administrasi lainnya.

Sedangkan menurut Pasal 4 ayat (4) Intruksi Presiden Republik Indonesia Nomor 15 Tahun 1983 tentang Pedoman Pelaksanaan Pengawasan, Pelaksanaan Pengawasan Oleh Aparat Pengawasan fungsional dilakukan oleh:

a. Badan Pengawasan Keuangan dan Pembangunan, selanjutnya disingkat BPKP.

b. Inspektoral jendral departemen (kementerian), aparat pengawas lembaga pemerintah non departemen (non kementerian) atau instansi pemerintah lain yang melakukan pengawasan terhadap kegiatan umum pemerintahan dan pembangunan dalam lingkungan departemen (kementerian) atau lembaga pemerintah non departemen (non kementerian) atau instansi pemerintah yang bersangkutan.

c. Inspektorat Wilayah Provinsi yang melakukan pengawasan umum atas jalannya pemerintahan daerah provinsi, baik yang bersifat rutin maupun pembangunan.

d. Inspektorat Wilayah Kabupaten/Kota yang melakukan pengawasan atas jalannya pemerintahan daerah kabupaten/kota, dan pemerintah desa/kelurahan di kabupaten/kota yang bersangkutan, baik yang bersifat rutin maupun pembangunan.

Sangat jelas bahwa pengawasan fungsional selalu harus dilaksanakan secara formal. Disamping itu prosesnya terikat pada waktu yang berlangsung dalam waktu yang relatif singkat. Sehingga ruang lingkup pengawasan fungsional meliputi beberapa hal sebagai berikut: a). kegiatan umum pemerintahan (termasuk pelayanan publik), b). pembangunan rencana pembangunan (dibidang pelayanan publik), c). penyelenggaraan pengurusan dan pengelolaan keuangan 
serta kekayaan negara (yang berkaitan dengan penyelenggaraan pelayanan publik), d). kegiatan badan usaha milik negara dan badan usaha milik daerah (yang ditugasi melakukan pelayanan publik), e). Kegiatan aparatur pemerintahan di bidang yang mencakup kelembagaan kepegawaian dan ketatalaksanaan (pelayanan publik).

\section{Pengawasan Eksternal Penyelenggara Pelayanan Publik}

Pengawasan eksternal penyelenggara pelayanan publik ini dilakukan oleh masyarakat, ombudsman, dan legislatif.

\section{Pengawasan oleh Masyarakat}

Pengawasan masyarakat terhadap penyelenggaraan pelayanan publik merupakan salah satu bentuk pengawasan eksternal, sebagaimana yang diatur dalam ketentuan Pasal 18 Undang-Undang Nomor 25 Tahun 2009 tentang Pelayanan Publik, dimana masyarakat berhak antara lain:

a. Mengawasi pelaksanaan standar pelayanan.

1) Mendapatkan tanggapan terhadap pengaduan yang diajukan.

2) Memberitahukan kepada pimpinan penyelenggara untuk memperbaiki pelayanan apabila pelayanan yang diberikan tidak sesuai dengan standar pelayanan.

3) Mengadukan pelaksana yang melakukan penyimpangan standar pelayanan dan atau tidak memperbaiki pelayanan kepada lembaga ombudsman.

4) Mengadukan penyelenggara yang melakukan penyimpangan standar pelayanan dan atau tidak memperbaiki pelayanan kepada Pembina penyelenggara dan ombudsman.

5) Mendapat pelayanan yang berkualitas sesuai denga asas dan tujuan pelayanan.

Apabila masyarakat merasa haknya untuk mendapatkan pelayanan yang berkualitas sesuai dengan asas dan tujuan pelayanan tidak terpenuhi, masyarakat berhak untuk menyampaikan pengaduan, laporan atau gugatan. Dalam perspektif hukum, pengaduan dilakukan terhadap penyelenggara yang tidak melaksanakan kewajiban atau melanggar larangan dan pelaksana yang memberi pelayanan yang 
tidak sesuai dengan standar pelayanan. Pengaduan tersebut disampaikan kepada penyelenggara, ombudsman, dewan perwakilan rakyat, dewan perwakilan rakyat provinsi, dan dewan perwakilan rakyat daerah kabupaten atau kota.

Sedangkan laporan yang dimaksud adalah tindakan hukum yang dilakukan masyarakat apabila penyelenggara yang di duga melakukan tindak pidana dalam penyelenggaraan pelayanan publik dan disampaikan kepada aparat penegak hukum (Kepolisian, Kejaksaan, dan KPK). Selanjutnya, gugatan merupakan tuntutan hukum yang disampaikan oleh masyarakat kepada penyelenggara atau pelayanan publik melalui pengadilan tata usaha negara atau melalui pengadilan negeri dalam hal penyelenggara melakukan perbuatan melawan hukum (aspek perdata) dalam penyelenggaraan pelayanan publik. Masyarakat (seluruh pihak, baik warga negara maupun penduduk maupun orang perseorangan, kelompok maupun badan hukum yang berkedudukan sebagai penerima manfaat pelayanan publik, baik secara langsung maupun tidak langsung) yang melakukan pengaduan dijamin hak-haknya oleh peraturan perundang-undangan.

\section{Pengawasan oleh Ombudsman}

Selain yang disebutkan di atas ada pula lembaga negara yang mempunyai kewenangan mengawasi penyelenggaraan pelayanan publik baik yang diselenggarakan oleh penyelenggara negara dan pemerintahan yaitu ombudsman. Penyelenggara negara dan pemerintahan yang baik hanya dapat tercapai dengan peningkatan mutu aparatur penyelenggara negara dan pemerintahan serta penegakan asas-asas pemerintahan umum yang baik. Untuk merealisasikan maksud tersebut diperlukan keberadaan lembaga pengawas eksternal (Ombudsman) yang secara efektif mampu mengontrol tugas penyelenggaraan negara dan pemerintahan.

Salah satu tugas ombudsman adalah memeriksa laporan atas dugaan maladministrasi dalam penyelenggaraan pelayan publik. Maladministrasi dimaksud adalah perilaku atau perbuatan melawan hukum, melampaui wewenang, menggunakan wewenang untuk tujuan lain dari yang menjadi tujuan wewenang tersebut, termasuk kelalaian atau pengabaian kewajiban hukum dalam penyelenggaraan pelayanan publik yang dilakukan oleh penyelenggara negara dan pemerintahan yang menimbulkan kerugian materiil dan immateriil bagi 
masyarakat (Pasal 1 Undang-Undang Nomor 37 Tahun 2008 tentang Ombudsman). Selanjutnya, laporan dimaksud adalah pengaduan atau penyampaian fakta yang diselesaikan atau ditindaklanjuti oleh Ombudsman yang disampaikan secara tertulis atau lisan oleh setiap orang yang telah menjadi korban maladministrasi (pasal 1 angka 4 Undang-Undang Nomor 37 Tahun 2008 tentang Ombudsman). Dalam melaksanakan tugas memeriksa laporan, ombudsman wajib berpedoman pada prinsip independen, non diskriminasi, tidak memihak dan tidak memungut biaya serta wajib mendengarkan dan mempertimbangkan pendapat para pihak dan mempermudah pelapor. ${ }^{17}$

\section{Pengawasan oleh Legislatif}

Pengawasan legislatif adalah pengawasan yang dilakukan oleh lembaga perwakilan rakyat baik di pusat maupun daerah. Atau disebut dengan istilah pengawasan representatif. Lembaga perwakilan rakyat dimaksud adalah Dewan Perwakilan Rakyat (DPR), Dewan Perwakilan Rakyat Provinsi (DPRD Provinsi), dan Dewan Perwakilan Rakyat Daerah Kabupaten/Kota (DPRD Kabupaten/Kota). Dalam Pasal 20A UUD Negara Republik Indonesia Tahun 1945, Dewan Perwakilan Rakyat memiliki fungsi, antara lain "fungsi pengawasan".

Selanjutnya, Dalam Pasal 69, Pasal 70 dan Pasal 71 Undang-UndangNomor 27 Tahun 2009 tentang MPR, DPR, DPD, DPRD, pada intinya bahwa "fungsi pengawasan DPR dilaksanakan melalui pengawasan atas pelaksanaan undangundang dan Anggaran Pendapatan dan Belanja Negara (APBN)". Dalam hal ini pengawasan terhadap pelaksanaan suatu Undang-undang termasuk Undangundang Nomor 25 Tahun 2009 tentang Pelayanan Publik; demikian pula pengawasan terhadap penggunaan keuangan negara yang bersumber dari anggaran pendapatan dan belanja negara, yang membiayai penyelenggaraan pelayanan publik yang diselenggarakan oleh penyelenggara negara dan pemerintahan.

\footnotetext{
17 Syahrul Ibad, Kewenangan Badan Perencanaan Pembangunan Kota (BAPPEKO) Malang dalam Perencanaan, Kordinasi, dan Pengendalian Tata Ruang Kota. Dialektika: Jurnal Ekonomi Dan Ilmu Sosial, (2018). 1(2), 23-48. Retrieved from:

http://ejournal.uniramalang.ac.id/index.php/dialektika/article/view/68
} 
Merupakan kewenangan DPR untuk melakukan pengawasan pelaksanaan penggunaan anggaran tersebut. Demikian pula DPRD provinsi pengawasan diatur dalam Pasal 292 dan pasal 293 dan DPRD Kabupaten/Kota pengawasan diatur dalam Pasal 343 dan Pasal 344 Undang-Undang Nomor 27 Tahun 2009, yang pada intinya bahwa "DPRD Provinsi dan DPRD Kabupaten/Kota melaksanakan pengawasan terhadap pelaksanaan peraturan daerah dan anggaran pendapatan dan belanja daerah provinsi, dan kabupaten/kota". Dalam hal ini termasuk pengawasan pelaksanaan peraturan daerah dan keuangan daerah yang bersumber dari anggaran pendapatan dan belanja daerah yang berkaitan dengan penyelenggaraan pelayanan publik yang dilakukan oleh Satuan Kerja Perangkat Daerah (SKPD).

\section{KESIMPULAN}

Dari beberapa hal dapat disimpulkan bahwa setiap tindakan pemerintahan baik dalam pengaturan ataupun dalam layanan pelayanan harus didasarkan pada peraturan perundang-undangan dan legalitas. Selain itu, fungsi hukum administrasi negara mewujudkan pemerintahan yang baik antara lain: pertama, fungsi normatif yaitu mengatur dan menentukan penyelenggaraan pemerintahan agar sesuai gagasan negara hukum. Kedua, fungsi instrumental pemberian kewenangan kepada pemerintah untuk menciptakan berbagai instrumen yuridis yang sesuai dengan undang-undang sebagai sarana untuk kelancaran penyelenggara pemerintahan. Ketiga, fungsi jaminan hukum yaitu bahwa masyarakat diberikan perlindungan bilamana tindakan penyelenggara administrasi negara tidak sesuai dengan undang-undang. Sedangkan hukum administrasi negara dalam meningkatkan penyelenggaraan pemerintah yang baik terdapat berbagai pengawasan yang diataur dalam perundang-undangan untuk mewujudkannya yaitu: pertama, pengawasan internal penyelenggara pelayanan publik terdiri dari pengawasan oleh atasan langsung, pengawasan oleh pengawas fungsional. Kedua, pengawasan eksternal penyelenggaraan pelayan publik terdiri dari pengawasan oleh masyarakat, pengawasan oleh lembaga Ombudsman dan pengawasan oleh lembaga legislatif. 


\section{DAFTAR PUSTAKA}

Basah, Sjachran, Eksistensi dan Tolok Ukur Badan Peradilan Administrasi Negara. Bandung: Alumni, 1985.

Hadjon, Philipus M., Pengantar Hukum Administrasi Indonesia. Yogyakarta: Gajahmada University Press, 1993.

Indroharto, Perbuatan Pemerintah Menurut Hukum Publik dan Hukum Perdata, Bahan Kuliah Pada Program Pendidikan Lanjutan Ilmu Hukum Bidang PTUN. Jakarta: Universitas Indonesia, 1992.

Iskratinah, "Pelaksanaan Fungsi Hukum Administrasi Negara”, makalah 2007

Manan, Bagir dan Kuntana Magnar, Beberapa Masalah Hukum Tata Negara Indonesia, Bandung: Alumni, 1997.

Manan, Bagir, Peranan Peraturan Perundang-undangan dalam Pembinaan Hukum Nasional. Bandung: Armico, 1987,

Marbun, F. dan Moh. Mahfud, Pokok-Pokok Hukum Administrasi Negara. Yogyakarta: Liberty, 1987.

Miles, M.B, Huberman dan Saldana, Qualitative Data Analysis, A Methods Sourcebook. ed. 3, USA: Sage Publication, 2014.

Muchsan, Beberapa Catatan tentang Hukum Administrasi Negara dan Peradilan Administrasi Negara di Indonesia, Liberty, Yogyakarta, 1981.

Purboprnoto, Kuntjoro, Beberapa Catatan Hukum Tata Pemerintahan dan Peradilan Administrasi Negara, Bandung: Alumni, 1975.

Ridwan HR., Hukum Administrasi Negara, cetakan ketujuh, Jakarta: PT Raja Grafindo Persada, 2011.

Siagian, Sondang P., Filsafat Administrasi, Jakarta: Gunung Agung, 1986.

Soemantri, Sri, Bunga Rampai Hukum Tata Negara Indonesia, Bandung: Alumni, 1992.

Syahrul Ibad, Kewenangan Badan Perencanaan Pembangunan Kota (BAPPEKO) Malang dalam Perencanaan, Kordinasi, dan Pengendalian Tata Ruang Kota. Dialektika: Jurnal Ekonomi Dan Ilmu Sosial, 2018, 1(2), 23-48. Retrieved from

http://ejournal.uniramalang.ac.id/index.php/dialektika/article/view/68

Versteden, C.J.N, Inleiding Algemeen Bestuurstrecht, Samsom H.D. Tjeenk Willink: Alphen aan den Rijn, 1984. 